\title{
The Role of the Village Government in Making the Rights and Obligations of State Citizens
}

\author{
Randi Setia Nugraha*, Prayoga Bastari \\ Graduate School \\ Universitas Pendidikan Indonesia \\ Bandung, Indonesia \\ *randisetianugraha2@gmail.com
}

\begin{abstract}
This study aims to determine the role of village government in raising awareness of citizen participation for village development, in particular how the village government raises awareness of citizen participation for development in Kisat Village, the process of building citizen participation, barriers and efforts in increasing citizen participation. The approach in this research using qualitative approach, with descriptive analytical method. informants are obtained by taking the people selected by the researcher based on their specific characteristics. The informants of this research are Kisat Village Government, BPD, Community Leader. Data collection techniques used were, interviews, literature studies, observation, and documentation. Data analysis techniques used are data reduction, data presentation, and data verification. The results of this study, it is known that the role of village government in raising awareness of citizen participation for development in Kisat Village realized by knowing the philosophy of earth pasundan namely silih asah, silih asih and silih asuh, karni by understanding the meaning of philosophical that citizens will participate and participate in village activities. Based on the data in the field, the spirit of gotong royong is reflected in the expression of the Sundanese Sabanda Sariksa, sabobot sapihanean, which means having a high awareness in the effort to create mutual ownership and spirit of the same fate including in developing the village.
\end{abstract}

Keywords—citizen participation; village government

\section{INTRODUCTION}

Indonesia's independent state on August 17, 1945 is a unitary state in the form of a republic. It is contained in Article 1 paragraph (1) of the 1945 Constitution of the State of the Republic of Indonesia which reads, "The State of Indonesia is a unitary State of the Republic." Therefore, there are no more countries, but the territory is divided into provinces, districts, municipalities and villages as set forth in Article 18 paragraph (1) of the 1945 Constitution of the Republic of Indonesia which reads, "The Unitary State of the Republic of Indonesia divided into provincial and provincial areas divided into districts and municipalities, each of which the provinces, districts and municipalities have local governments, which are regulated by law. "Furthermore, under the provisions of Article 2 paragraph (2) -The Decree No. 23 of 2014 on Regional Government, it is explained that "Districts / municipalities are divided into subdistricts and / or villages." The

regulation of the village currently refers to Law No. 6 of 2014 on Villages. Based on the provisions of Article 1 paragraph (1) of Law Number 6 Year 2014 Villages shall be villages and customary villages or called by other names, hereinafter referred to as Villages, is a legal community unity with borders authorized to regulate and administer government affairs, local community based on community initiative, origin rights, or traditional rights recognized and respected within the government system of the Unitary State of the Republic of Indonesia [1].

The village is located in a regency / municipality and is the lowest government organization, so based on its position closest to the people. Under the provisions of Article 1 subarticles 2 and 3 of Law No. 6 of 2014 on Villages it is explained that "Village administration is the administration of government affairs and the interests of local communities in the system of government of the Unitary State of the Republic of Indonesia". Furthermore, what is meant by "The village government is the village head or the so-called other name assisted by the village apparatus as the element of the village administration". The manifestation of village government affairs is carried out by the village government and the Badan Permusyawaratan Desa (BPD) in arranging and managing the interests of the local community [1]

From the above article the obligation of the village government is one of them is to develop the life of democracy, the democracy in question, is not a formal democracy as practiced at the state level, the political party as the main instrument. Democracy here is understood as a practice that prioritizes consensus in every decision-making, involving villagers either directly or through representative institutions.

The democratic life in the village cannot be separated from the rights and obligations of the citizens. Democracy life is always related to citizen participation because with the participation of citizens then the life of democracy goes well. With such existence, the existence of village government becomes very important and strategic. The role of village government is not enough just the relationship between villagers and village government. However, the lives of individuals and groups in the fulfillment of their right to participate, accommodate aspirations, in various channels of social institutions and obey all applicable laws and regulations. As a government institution, the village government is the spearhead in fostering a democratic life system with the participation of its citizens. 
Citizen participation in Law No. 6 of 2014 on villages, section 82 regulates citizen participation in the form of [1]:

- Participating in village meetings

- Providing aspirations, suggestions, and oral or written opinions

- Obtaining information on the plans and implementation of Village Development

- Monitoring the implementation of Village Development

- Reporting monitoring results and various complaints against the implementation of Village Development to the Village Government and Village Consultative Body (BPD)

Based on the above article the fulfillment of rights and obligations, namely the participation of villagers is very important both as a tool to achieve development goals in the village as an effort to collect the aspirations of citizens by village consultation (musdes) and village development planning (musrenbangdes). This is also stated in Article 28 of the 1945 Constitution which reads "freedom of association and assembly, issue of thought with oral and written and so on is established by law".
The Village Minister, Marwan Jafar (www.republika.co.id), admits there are still many obstacles in implementing the Village Law [2]. These barriers are also present in the issue of citizen participation. He called it an obstacle in terms of village democratization. Marwan said the democratization of the village still faces administrative administrative obstacles. Local government apparatuses tend to perform compliance actions from the "Center" to control the village administration, including in the use of village funds. Whereas the Village Law has recognized the authority possessed by the village in organizing and managing the interests of the community based on the rights of origin, customs, and socio-cultural values in a democratic and participative manner. "Village democratization is also constrained by the lack of substantive and constructive participation from the village community. It is in this dimension that the government and regional governments can play an active role in fostering and empowering the village community in order to improve the quality of participation their, "Marwan explained in a press release on Tuesday (5/01) [2].

The results of research conducted by the Center for Political Studies (Puskapol) FISIP University of Indonesia on citizen participation in village governance mentions two challenges of participation of villagers in developing their village [3]:

TABLE I. Challenges OF VILlagers' PARTICIPATION

\begin{tabular}{|l|l|}
\hline Closure of Village Government And BPD To Involve Citizen \\
\hline 1. & $\begin{array}{l}\text { BPD do not perform their functions optimally as supervisors of village } \\
\text { government performance and community representation. The } \\
\text { relationship between BPD and the village government is closed. "They } \\
\text { do not share information on the results of deliberation and monitoring of } \\
\text { performance to the villagers. } \\
\text { Relationships between government, village elites and citizens also } \\
\text { collect the supervisory functions in the village } \\
\text { Lack of citizens' involvement in village consultation and village } \\
\text { development meetings. invite community leaders, RTs and RWs Not to } \\
\text { invite people outside the structure to the village so that the participation } \\
\text { of low-income citizens in musdes and musrenbangdes } \\
\text { Residents have not realized that BPD can be asked to hold musdes } \\
\text { anytime if needed to discuss the problem or strategic matters }\end{array}$ \\
4.
\end{tabular}

Based on the above data it can be explained that the importance of citizen participation, especially the villagers becomes the central issue, because in running the village government the necessity of citizen participation so that if active citizen participation then the village will progress. Badan Permusyawaratan Desa (BPD) also has a function as a forum for participation of villagers are required to be more active role. As a consequence of the implementation of the bottom-up planning system, rural communities are also required to participate actively in the decision-making process involving various aspects related to village development plans through the Badan Permusyawaratan Desa (BPD) in the village.

Therefore, education has a broader purpose. Education as a means of intelligence and increased insight, participation and
Citizens Because Lack of Knowledge of Village Governance and Opportunity Participation Citizens of

1. Apatis citizens against musrenbangdes, because the proposed village development program has never communicated the results and its follow-up to the residents so that the residents consider the proposal not to be responded, although it is very rarely the results of musrenbangdes accommodated in RPJMD.People

2. still do not understand the difference between musdes and musrenbangdes, 1 that is similar to musrenbangdes

3. There is already a citizen initiative to supervise the performance of the village head but the supervision has not been running optimally, because the villagers do not understand the flow of policy making and the relevant documents to become the instrument of supervision.

4. There has been the experience of citizens for the implementation of transparent organizational governance through assistance in the era of PNPM, but it is temporary (during assistance) because the citizens are not encouraged to independently be able to conduct monitoring of village governance in a sustainable way.

a. Source: [3]

intellectual citizens directed to be able to form citizens who have strong character. The formation of the character of citizenship is done on an ongoing basis, as well as the proverb "education until the end of life", the process of consolidation of the three major components of civic education quality, namely knowledge of citizenship (civic knowledge), skills citizenship (civic skills), and the nature of citizenship (civic dispositions) is also done in a sustainable manner given the dynamic nature of society [4].

In this research, I as a researcher chose Village Kisat. Kisat Village is a village located in Subang Regency. Kisat Village area includes 4 dusun, $6 R W$, and $28 R T$. Kisat is a village with beautiful natural scenery and beautiful and rich in traditional arts and culture that makes it a single ikon. Based on preresearch conducted by the writer in the field there are some 
problems arising from the aspect of the form of public participation in the implementation of development in Kisat Village has not run optimally, where the community as a whole has not gained the same opportunity in contributing thoughts and still constrained time and place. Lack of role of RT chairman in providing information and coordination to involve villagers in village consultation, mutual assistance activities, and low participation of people involved in non-physical development in the form of funds or materials such as road infrastructure improvement, camping post and other public facilities, because the local community is too expecting aid from the government alone.

Underlying the importance of the role of village government in promoting a village, the theme of this writing is crucial to study. Departing from the things that, researchers then interested to lift the title of research entitled "The Role of Village Government in Developing Rights and Duties of Citizens".

\section{THEORETICAL REVIEW}

\section{A. Concept Village}

According to HAW Wijaya cited by Eni Kusdarini, basically historically the village is the forerunner of the formation of political and governmental society in Indonesia before the nation and nation of Indonesia are formed [5]. Like Bintarto states that the village is an autonomous institution with its own traditions, customs and laws and is relatively independent [6]. In addition, the village is a geographical manifestation brought about by the economic, political, and cultural physiographic elements that are present in relationships and mutual influences with other regions.

Soenardjo in his book "Brief Overview: Village Governance and Village" suggests that the village is a community entity based on adat and customary law residing within a certain area of its boundaries; have a strong bond of birth and mind, both because of their descent and because they share political, economic, social and security interests; has a jointly selected organizational structure; has a certain amount of wealth and is entitled to carry out its own household affairs [7].

Based on the explanation of the above villages, it can be concluded that the village is a legal entity that has a territorial boundary, has the authority to organize and manage the affairs and interests of the local community based on the origin and customs that are recognized and established within the system of government of the Unitary State of the Republic of Indonesia, the village is under the administration of the district / city so that it is the lowest and closest unit of government with the community.

Village administration is administered by the village government and Village Consultative Board (BPD). Based on the provisions of Article 1 Sub-Article 2 of Law Number 6 Year 2014 concerning Villages, it is stated that "Village Governance is the administration of government affairs and the interests of local communities in the system of government of the Unitary State of the Republic of Indonesia". Based on the provisions of Article 1 Sub-Article 3 of Law Number 6 Year
2014 concerning Villages, it is stated that "The village government is the village head or called other name assisted by the village apparatus as the element of the village administration."

Based on the above article the obligations of the village government are: (i) holding firm and practicing Pancasila; (ii) obey and enforce regulations; (iii) implement the principles of village governance; (iv) cooperate with all stakeholders; and (v) coordinate village development in a participatory manner.

\section{B. Concept of Citizens}

Every country must have citizens. In terms of citizens in the context of Indonesian vocabulary refers to or translations of the word "citizen" in English or citoyen in French. Furthermore, defines "citizens as citizens of a particular country" [8]. In the law of the Republic of Indonesia Number 12 of 2006 on the Citizenship of the Republic of Indonesia, the meaning of the citizens referred to in article 1, paragraph 1 is a citizen of a country which is stipulated under the laws and regulations. Verse 2 citizenship is all matters relating to citizenship. Furthermore Turner states "Citizen is member of group living under certains laws are set and enforced by the people who government, or rule the group [9]. Those who take part in ruling the group are, together, known as a goverment. A citizen, then is a member of a group living under the rule of a government"

Based on the above explanation that a citizen is a person of the life of a community group with certain rules. Rules are a set of norms that empower citizens for the state, or roles in their community groups. They have the function of living together, knowing and understanding other laws and regulations in that country.

Similarly, good citizens are citizens with knowledge, skills and civic attitudes that include believing and devoted citizens to God Almighty, intellectual, emotional, social, spiritual citizens, has a concern for other citizens, has a sense of pride and responsibility, always based on ethics in dealing with each other, able to participate in the life of society, nation and state and citizens who have a sense of nationality and love of the country.

Based on Wahab and Sapriya that "good citizens (to be good citizens) are citizens who have intelligence (civic intelligent) both intellectual, emotional, social, and spiritual; have a sense of pride and responsibility (civic responsibility) and able to participate in community life and civic (participation) in order to grow a sense of nationality and love of the homeland " [10]. From this view it is understood that the good citizens of intellectual, emotional, social, and spiritual intelligence in the citizens, have a sense of pride and responsibility, and citizens are able to participate in the life of society and state to grow a sense of nationality and love of the country.

\section{The Concept of Participation}

"Participation is define as mentally and emotional involvement of a person in a group of situations which encourages him to group goals and share responsibility in 
them". Davis defines participation as the individual's mental and emotional involvement in a particular group situation that encourages him to support or support the achievement of group goals and take responsibility for them. According to Juliantara in Deviyanti participation is defined as "the involvement of every citizen who has rights in decision-making, either directly or through the intermediation of a legitimate institution representing his interests, public participation is freedom of speech and participation in a constructive manner" [11].

Citizen participation is needed in a country. The advancement of a country depends on its citizens. Citizen participation can be active and passive. Therefore civic education can lead citizens to participate actively in accordance with the expectations and goals of the state. There are several forms of community participation in the development stage. According to Ericson in slamet the form of community participation in development is divided into three stages [12]:

- Participation in the planning stage (idea planing stage). Participation in this stage is the maxim of one's involvement in the stage of preparing plans and strategies in preparing the budget committee in a project. The community participates by providing suggestions, suggestions and criticisms through meetings.

- Participation in the implementation stage (implementation stage). Participation at this stage means the involvement of a person at the stage of execution of a project work. The community here can provide energy, money or materials and ideas as one form of participation in the work:

- Participation in the utilization (stage utilization) of participation at this stage means the inclusion of someone at the stage of utilization of a project after the project is completed.

Taking into account some form of participation and the way to achieve it as described above, it appears that the main criterion used to determine community participation is the involvement without having to question the underlying factors and encourage such engagement. As Nelson in Hessel mentions two kinds of participation, namely [13]:

- Horizontal participation, ie participation among fellow citizens or members of the community, where the community has the capacity to initiate jointly a development activity.

- Vertical participation, ie participation between the community as a whole with the government, in relationships where society is in a position of followers or clients.

Thus, a person is said to participate in a development activity if the individual really engages himself as a whole with his mental and emotional, rather than just being present and passive towards the activity. The sense of responsibility as one element of participation, as it is a decisive aspect in individual decision-making to participate in any development activities. The opinion of Hicks is also quoted by Hessel as formulating a sense of responsibility as a quality of society to develop independently, when the conscious and free person choose and approve all things, absorb a value, or accept a task.

\section{RESEARCH METHODS}

Research on the role of village government in fostering citizens' rights and obligations using a qualitative approach. The Qualitative Approach is a study that uses a naturalistic approach to finding and finding understanding or understanding of phenomena in a particular contextual setting. Furthermore Moleong states that qualitative research is a procedure that produces qualitative data in the form of written or oral words of the people and behavior observed [14]. This research will discuss and describe the role of village government in fostering citizens' rights and obligations, the focus of this research is how to build citizen participation to realize good and smart citizen.

The method used in this research is the descriptive method of research method to describe the situation or events that are explanatory or describe only and do not need to look for relationships, test the hypothesis and get meaning and implications. Descriptive method describes the various information by conducting a critical analysis of the information or data obtained data. As Emzir points out in the descriptive method, the data collected preferably takes the form of words or images rather than numbers. The results of written research contain excerpts from the data to illustrate from providing proof of presentation. The data includes interview data, field notes, videotape, personal documents and other official records [15].

The determination of participants in this study was conducted by purposive method. According to Nasution, the determination of research subjects by purposive is done by taking the people who are selected by the researcher based on the specific characteristics they have, for example people with a certain level of education, have a certain age, who have been active in the activity community [16]. Data collection through interview techniques, observation, and documentation. Data analysis includes data reduction, data presentation and conclusion drawing. The technique of testing the validity of the data using source triangulation.

\section{RESULTS AND DISCUSSION}

Kisat village is a village located in the work area of Ciater Sub district Subang Regency, in the south precisely in the northern slope of Tangkuban Parahu mountain which is surrounded by tea plantation owned by PTPN VIII Ciater. Kisat Village has 10 kampung, 4 Dusun, $6 \mathrm{RW}$ and $28 \mathrm{RT}$. Culture in the Village Kisat very much one of them is on the eve of the planting season and rice harvest in every corner of rice fields are given "Pupuhunan" sanctioned sawen janur and plant plants symbols such as Handeuleum, Jawer Kotok, Hanarusa and Tamiang pugur, in the form of flowers in the hope that all these symbols can be interpreted and applied in everyday life, especially the farmers so that the agricultural produce they get will bring blessings.

Next based on the results of data analysis through interviews, literature studies, observation, and documentation, 
it is found that the role of village government cisaat in fostering the rights and obligations of villagers is good it can be seen from the existing development in the village cisaat from year caught have increased in the development process in particular the involvement of citizens is very influential because of the involvement of citizens, the government is able to facilitate what the citizens want for the progress of their village.

Based on the results of research Kisat Village villagers know, capable, and supervise. The villagers of Kisat are able to fight against the arbitrariness begins with, the villagers of Kisat must know, gathered in the forums of the village meeting to discuss the problems faced in the village and know the development programs in the village. After that the villagers of Kisat must be able to formulate the discussion result from a list of proposals that will be submitted to the leader. Furthermore, Kisat Village residents also participated in overseeing the work of the village government, because village supervision is the right and responsibility of the villagers of Kisat

According to Juliantara in Deviyanti, participation is defined as "the involvement of every citizen who has the right to manufacture decisions, either directly or through the intermediation of the legitimate institution representing its interests, the participation of the people is freedom and speaks and participates constructively " [11].

In line with the above community in Kisat Village still apply the philosophy of land Pasundan namely silih asah (mutual mind-numbing, each other remind), penance (counseling each other) and compassionate (mutual lovei) where the combination of word pen with each word asah, asah, make a compound contains the meaning of value transformation that comes from the substance of the meaning of values: asih, asah, foster in the life between people in the reality of community life, so as to build a harmonious interdependence to improve the quality of humanity. Orientation of values contained in the meaning of silas in essence to improve the quality of human resources in social life. Based on the data in the field, the spirit of mutual help of the community is reflected in the expression of the Sundanese Sabanda Sariksa, sabobot sapihanean, which means having a high awareness in the effort to create mutual ownership and spirit of the same fate including in developing the village.

So that with the philosophy of community participation in village life will emerge. Where citizens apply in everyday life for example citizens participate in musyawarah, ranging from $R T, \quad R W$, Musdus (Musyawarah Dusun) and Musdes (Museswarah Desa). Citizens provide ideas and ideas in every deliberation that produces village policies in development. According Ericson in slamet, form of community participation in development, namely: participation in the planning stage (idea planing stage) [12]. Participation in this stage is the maxim of one's involvement in the stage of preparing plans and strategies in preparing the budget committee in a project. The community participates by providing suggestions, suggestions and criticisms through meetings.

\section{CONCLUSION}

Based on the research findings that have been described the role of village government in fostering the rights and obligations of citizens are: 1) Kisat Village community powerless know, capable, and supervise. The villagers of Kisat are able to fight against the arbitrariness begins with, the villagers of Kisat must know, gathered in the forums of the village meeting to discuss the problems faced in the village and know the development programs in the village. After that the villagers of Kisat must be able to formulate the discussion result from a list of proposals that will be submitted to the leader. Furthermore, Kisat Village residents also participated in overseeing the work of the village government, because the supervision in the village is the right and responsibility with the people of Kisat Village. 2) still apply the philosophy of the Sundanese community that is silih asah, silih asih and silih asuh by establishing ideas or ideas during deliberation for village development, arise self-help community to build the village and the value of mutual gotong royong. These are all forms of participation of the villagers in promoting their village, as well as the spirit of mutual help of the community as reflected in the expression of the Sundanese "Sabanda Sariksa, sabobot sapihanean", which means having a high awareness in the effort to create mutual ownership and spirit of the same destiny, including in promoting the village.

\section{REFERENCES}

[1] Undang-Undang Republik Indonesia No 6 Tahun 2014 Tentang Desa

[2] Republika.co.id,Jakarta.tersedia.di. http://www.republika.co.id/berita/koran/teraju/16/01/05/o0h548memperkuat-partisipasi-perempuan-di-desa.

[3] http://www.puskapol.ui.ac.id/publikasi_puskapol/partisipasi-warga-didesa-mendorong-kepemimpinan-perempuan.html, diakses pada Kamis, 11 Januari 2018, pukul 22.15 WIB.

[4] Branson, Belajar Civic Education Dari America, Yogyakarta: LKiS, 1999.

[5] E. Kusdarini, Dasar-Dasar Hukum Administrasi Negara, Yogyakarta: UNY Press.

[6] 1. R. Bintarto, Buku Penuntun Geografi Sosial, Yogyakarta: UP Spring, 1968.

[7] Soenardjo, and R.H. Unang, Singkat Tentang: Pemerintahan Desa dan Kelurahan, Tarsito, Bandung, 1984.

[8] E. Danial, Economi Civic (Membina Warga Negara; Bersikap dan Berpartisipasi Dalam System Ekonomi Nasional Untuk Meningkatkan Kesejahteraan Masyarakat, Bandung: Laboratorium PKn UPI, 2007.

[9] J.T. Turner, J. C. Long, S. J Bowes, and J. E. Lott, CIVICS Citizen in action, Columbus Ohio: Merrill Publishing Company, 1990.

[10] Wahab and Sapriya, Teori dan Landasan Pendidikan Kewarganegaraan (PPKn), Bandung: Alfabeta, 2011.

[11] D. Deviyanti, "Studi tentang Partisipasi Masyarakat dalam Pembangunan di Kelurahan Karang Jati Kecamatan Balikpapan Tengah," eJournal Administrasi Negara, vol. 1, no 2, pp. 380-394, 2013.

[12] Y. Slamet, Pembangunan Masyarakat Berwawasan Partisipasi, Surakarta: Sebelas Maret University Press, 1994.

[13] N. S. T Hessel, Manajemen Publik, Jakarta: PT. Grasindo, 2005.

[14] J. L. Moleong, Metode Penelitian Kualitatif, Bandung: Remaja Rosdakarya, 2005.

[15] Emzir, Metodologi Penelitian Kualitatif dan Analisis Data, Jakarta: PT Raja Grafindo Persada, 2010.

[16] S. Nasution, Metode Penelitian Naturalistik Kualitatif, Bandung: Tarsito, 2009 . 